\title{
ZMIENIAĆ RZECZY W ZNAKI. KOD PRZEDMIOTOWY W TRADYCJI BOŻEGO CIAŁA Z KWIETNYMI DYWANAMI W SPYCIMIERZU
}

\begin{abstract}
Zarys treści: Artykuł stanowi semiotyczną analizę przedmiotów (materiałów, narzędzi, przedmiotów kultu) wykorzystanych w Spycimierzu (województwo łódzkie, powiat Poddębice, gmina Uniejów) podczas święta Bożego Ciała. Wieś ta wyróżnia się nadzwyczaj bogatym wystrojem, a szczególnie kwietnymi dywanami 2-kilometrowej długości układanymi na całej trasie procesji eucharystycznej. Autorka do analizy obrzędowego kodu przedmiotowego zastosowała teorię semioforów Krzysztofa Pomiana. SEMIOForami według niej są dywany kwiatowe, bramy i ołtarze - przedmioty w najwyższym stopniu sakralne w czasie mszy świętej i procesji. Powstają one z i za pomocą RZECZY - materiałów, narzędzi, przy asyście MEDIów - aparatów i kamer. Po procesji następuje etap desakralizacji SEMIOFORów i wytracania przez nie symbolicznych funkcji oraz wysokich wartości. Część z materiałów użytych do stworzenia SEMIOFORów zostanie przechowana na następny rok stając się RZECZAMI, część jako oDPADY trafi na kompostowniki, zamieniając się w CIAŁA - glebę, z której w kolejnym roku wyrosną kwiaty. Wobec tego, że kwiaty posłużą do ułożenia kwietnego dywanu czy ozdobienia ołtarza, opisany obieg przedmiotów można nazwać spycimierskim kontinuum.
\end{abstract}

Słowa kluczowe: Spycimierz, Boże Ciało, kwiatowe dywany, semiofory, Krzysztof Pomian, kod przedmiotowy

Podstawę metodologiczną niniejszego artykułu stanowi koncepcja N.I. Tołstoja ${ }^{1}$, powstała w latach $90 . \mathrm{XX}$ w. z inspiracji teoriami tartusko-mo-

* Katarzyna Smyk, dr hab., prof. UMCS, Uniwersytet Marii Curie-Skłodowskiej, Instytut Nauk o Kulturze, pl. M. Curie-Skłodowskiej 4, 20-031 Lublin, e-mail: k.smyk@umcs.pl

${ }^{1}$ N.I. Tolstoj, Jazyk i narodnaja kul'tura. Očerki po slavjanskoj mifologii i etnolingvistike, Moskva 1995, s. 63-65; N.I. Tołstoj, Język a kultura (niektóre zagadnienia słowiańskiej etnolingwistyki), przeł. L. Zienkiewicz, J. Bartmiński, „Etnolingwistyka. Problemy Języka i Kultury” 1992, t. 5, s. 21-22. 
skiewskiej szkoły semiotycznej². N.I. Tołstoj założył, że każdy obrzęd może być przedstawiony jako tekst, w którym daje się wydzielić poziom werbalny i rytualny, i który jest budowany ze znaków języka obrzędowego z zastosowaniem tradycyjnej obrzędowej składni. Na tej podstawie N.I. Tołstoj opracował teorię morfologii obrzędu, wedle której jest on zbudowany ze znaków należących do różnych systemów semiotycznych ${ }^{3}$, co przekłada się na użycie znaków kodu werbalnego, temporalnego, przestrzennego, personalnego, akcjonalnego, muzycznego, przedmiotowego itd. W zależności od gatunku tekstu obrzędowego, mogą one występować w różnych proporcjach (np. obrzędowe milczenie - bez kodu werbalnego; biesiada weselna - z przewagą kodu muzycznego czy kinezycznego itd.). Wszystkie kody współtworzą sens obrzędu dzięki „,tendencji do maksymalnej synonimiczności”, polegającej na wyrażaniu danej treści za pomocą jak największej liczby symboli ${ }^{4}$. Tekst-obrzęd to zatem sekwencje symboli, których forma i szyk modelowane są przez obrzędową syntagmatykę, zapewniającą realizację spójnej semantycznie całościs.

Spróbujmy tę teorię przyłożyć do spycimierskiej, wyjątkowej w skali kraju i Europy tradycji Bożego Ciała. Święto to, oficjalnie nazywane Uroczystością Najświętszego Ciała i Krwi Chrystusa (łac. Sollemnitas Sanctissimi Corporis et Sanguinis Christi), funkcjonuje w Kościele katolickim od XIII wieku, w Polsce - od początku XIV w. Ewoluowało ono w formie i treści, od adoracji i pokuty, aż po współczesną funkcję zbiorowej manifestacji w przestrzeni publicznej wiary i triumfu Chrystusa nad śmiercią, z centralnym dla całego chrześcijańskiego świata elementem celebracji - procesją ${ }^{6}$. Procesja była znana w Europie Zachodniej od XIV w., zaś w Polsce - od XV w. i zawsze wyglądała wyjątkowo okazale i spek-

2 J. Łotman, Uniwersum umysłu. Semiotyczna teoria kultury, przekł. i przedmowa B. Żyłko, Gdańsk 2008; B. Żyłko, Semiotyka kultury. Szkoła tartusko-moskiewska, Gdańsk 2009; B. Żyłko, Kultura i znaki. Semiotyka stosowana w szkole tartusko-moskiewskiej, Gdańsk 2011.

${ }^{3}$ N.I. Tolstoj, Jazyk i narodnaja kul 'tura ..., s. 63-64; N.I. Tołstoj, Język a kultura ..., s. 21-22; por. M. Segalen, Obrzędy i rytuaty współczesne, przekł. J.J. Pawlik, Warszawa 2009, s. 25.

4 N.I. Tolstoj, Jazyk i narodnaja kul tura ..., s. 65. Tołstoj przeniósł też na grunt badania obrzędu również semiotyczną ideę symbolu (np. K. Piątkowski, Semiotyczne badania nad kultura w etnologii. Studium metodologiczne, Toruń 1993, s. 83-90; B. Żyłko, Semiotyka kultury..., s. 122-236), jak również szerokie rozumienie znaku jako fenomenu składającego się z formy i treści.

5 N.I. Tolstoj, Jazyk i narodnaja kul tura ..., s. 63, 65.

6 R. Hołda, Boże Ciało. Święto, ceremonia i performans, „Journal of Urban Ethnology” 2013, nr 11, s. 67; M. Rubin, Corpus Christi. The Eucharist in Late Medieval Culture, Cambridge University Press 1991, s. 243; Z. Zalewski, Święto Bożego Ciała w Polsce do wydania Rytuatu Piotrkowskiego (1621), „Studia z Dziejów Liturgii w Polsce” 1973, t. 1, s. 134; H. Zaremska, Procesje Bożego Ciała w Krakowie w XIV-XVI wieku, [w:] B. Geremek (red.), Kultura elitarna a kultura masowa w Polsce późnego średniowiecza, Wrocław 1978, s. 34, 117-118; K. Pozorski SDB, Włoskie pochodzenie tradycji dekoracyjnych uroczystości Corpus Domini, „Biuletyn Uniejowski” 2019, t. 8, s. 70-71; B. Ciesielska-Szynal, Dekoracje kwiatowe trasy procesji Bożego Ciała w Spicimierzu, „Sieradzki Rocznik Muzealny” 1996, nr 10, s. 31-32. 
takularnie ${ }^{7}$. Ostatecznie nabrała formy bardzo rozbudowanej, z konstruowaniem i ozdabianiem czterech ołtarzy, przy których odbywa się część liturgii słowa i między którymi w odpowiednio tradycyjnie uformowanym orszaku przechodzą wierni; z brzozami, kwiatami ozdabiającymi ołtarze i trasę przemarszu (np. okna i fasady domów wzdłuż trasy), wraz z innymi atrybutami chrześcijańskimi (chorągwie, chorągiewki, fotografie duchownych lub symbole eucharystyczne);

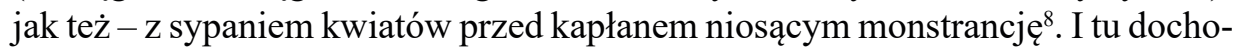
dzimy do wyróżnika tradycji Bożego Ciała w Spycimierzu, małej miejscowości ${ }^{9}$ w gminie miejsko-wiejskiej Uniejów w powiecie poddębickim w województwie łódzkim, położonej około $2 \mathrm{~km}$ od Uniejowa, będącej ośrodkiem parafii zgromadzonej wokół kościoła pw. Podwyższenia Krzyża Świętego ${ }^{10}$.

Spycimierzanie i mieszkańcy innych miejscowości należących do parafii, zachowując znane w całej Polsce sposoby obchodzenia święta (ustawianie i ozdabianie ołtarzy kwiatami oraz brzózkami, sypanie kwiatków przez dziewczynki, procesja z feretronami, sztandarami itp.), dodają też swój niezwykły świąteczny element: kwietne dywany. Układają bowiem oni na wyznaczonych odcinkach drogi ${ }^{11}$ szerokie na 1,5-2 m, dywany kwiatowe o różnorodnych wzorach ${ }^{12}$, łączące się w jeden kobierzec o długości około $2 \mathrm{~km}$. Ustawiają też bramy (ostatnimi laty dwie, kiedyś było ich więcej), wykonane z bali, oplecione igliwiem i ozdobione kwiatami. „Dekorowanie trasy procesji stało się tutaj swoistym dziełem artystycznym, w którym bierze udział cała społeczność parafii Spycimierz"13,

7 W. Kaźmierczak, Procesja Bożego Ciała z tradycją kwietnych dywanów w Spycimierzu jako krajowe dziedzictwo niematerialne, „Biuletyn Uniejowski” 2018, t. 7, s. 68.

8 Przykładowa literatura przybliżająca historię, ideę, interpretacje, przemiany i współczesność uroczystości Bożego Ciała zob. R. Hołda, Boże Ciało...; H. Zaremska, Procesje Bożego Ciała...; Z. Zalewski, Święto Bożego Ciała...; B. Ogrodowska, Zwyczaje, obrzędy i tradycje w Polsce. Maly stownik, Warszawa 2001, s. 23-25; M. Douglas, Symbole naturalne. Rozważania o kosmologii, tłum. E. Dżurak, Kraków 2004, s. 88; J. Nowiński, Ars eucharistica. Idee, miejsca i formy towarzyszace przechowywaniu eucharystii w sztuce wczesnochrześcijańskiej i średniowiecznej, Warszawa 2000; M. Rubin, Corpus Christi...; P. Burke, Kultura ludowa we wczesnonowożytnej Europie, tłum. R. Pucek, M. Szczubiałka, Warszawa 2009, s. 228 i in.

9 Według danych Głównego Urzędu Statystycznego wsie parafii Spycimierz liczą kolejno: Spycimierz - około 340 osób, Spycimierz-Kolonia - 59 osób, Zieleń - 100 osób, Człopy - około 250 osób. Razem daje to niecałe 750 mieszkańców. GUS - Bank Danych Lokalnych, online: https://bdl.stat.gov.pl/BDL/metadane/teryt/miejscowosci/1434\# [dostęp: 15.03.2020].

${ }^{10}$ Przyjmuje się, że Spycimierz jest siedzibą parafii od 900 lat; T. Figlus, Rozwój układu ruralistycznego Spycimierza na tle dziejów osadnictwa w świetle badan geograficzno-historycznych $i$ archeologicznych, „Biuletyn Uniejowski” 2015, t. 4, s. 75-80.

${ }^{11}$ Spycimierzanie wzdłuż swojej posesji, wzdłuż posesji swojej rodziny; uczniowie z rodzicami i nauczycielami - wzdłuż szkoły; mieszkańcy innych wsi - odcinki np. przy plebanii itd.

${ }^{12}$ Szczegółową analizę formy i symboliki najnowszych wzorów opisałam w artykule: K. Smyk, Spycimierskie kwietne dywany na Boże Ciało - typologia i symbolika wzorów, „Biuletyn Uniejowski” 2019, t. 8, s. 35-65.

${ }^{13}$ W. Kaźmierczak, Procesja Bożego Ciała..., s. 68. 
włącznie z przyjezdnymi gośćmi, młodzieżą i dziećmi. Wymaga to ogromnego nakładu pracy i logistyki, dzięki czemu spaja wspólnotę wielu generacji parafian i ich przyjaciół spoza Spycimierza. Planowanie dywanów, ich wyglądu, przydziału miejsca usypywania, podzielenie się rolami wewnątrz wspólnoty itd. trwa kilka miesięcy. Działania zaś związane z wykonaniem dywanów - głównie z pozyskaniem, przebraniem i przechowaniem dużej ilości materiału roślinnego - są przemyślane, organizowane logistycznie obejmują kilka dnia przed Bożym Ciałem. W wigilię święta wieś jest dokładnie sprzątana, zaś samo układanie zaczyna się w Boże Ciało od rana, by na Mszę Świętą o 17.00 droga przez wieś była już gotowa do przejścia procesji eucharystycznej. Po procesji z kolei mieszkańcy w ciągu paru godzin sprzątają wieś i tym sposobem pracochłonne kwietne kobierce znikają bez śladu ${ }^{14}$.

Uwzględniając perspektywę semiotyczną, w strukturze święta spycimierskiego można wyznaczyć następujące znaki pochodzące z kolejnych kodów semiotycznych:

- kod akcjonalny/kinezyczny - działania służące przygotowaniu ozdób wsi; pozyskiwanie materiałów na dywany, bramy i ołtarze; zachowania podczas mszy i procesji; sprzątanie przed i po procesji itd.;

- kod personalny - role społeczne aktywizowane z okazji święta, jak osoby wybierające się po kwiaty na pola, łąki i do ogrodów; liderzy-kierownicy rodzin sypiących dywany; osoby układające dywany; osoby rysujące wzory; osoby skubiące kwiaty; liderzy i członkowie zespołów zajmujących się ustawianiem bram, ołtarzy, sprzątaniem itd.; role przyjmowane w orszaku procesji eucharystycznej; turyści-widzowie i turyści-pielgrzymi itd.;

- kod werbalny - sposób porozumiewania się zespołów podczas pracy; modlitwy podczas mszy; rozmowy turystów z parafianami; napisy wplatane w kwiatowe dywany ${ }^{15}$; wspomnienia wyjątkowych świąt; legendy i podania o powstaniu i historii kwietnych dywanów ${ }^{16}$ itp.;

- kod słowno-muzyczny-przejawia się w warstwie fonicznej świątecznej liturgii, z pieśniami napisanymi specjalnie dla parafii, jak np. pieśń autorstwa W. Smętkiewicza do muzyki M. Matuszewskiego, rozpoczynająca się od słów Od dwóch stuleci, zgodnie z tradycja Wierny lud zmierza w Twe, Jezu, święto Bożego Ciała do Śpicimierza (Spycimierz KK) ${ }^{17}$;

${ }^{14}$ Por. B. Ciesielska-Szynal, Dekoracje kwiatowe..., s. 33-35.

${ }^{15}$ K. Smyk, Spycimierskie kwietne dywany..., s. 59-60.

${ }^{16} \mathrm{~K}$. Smyk, Kwietne dywany na Boże Ciało w przekazach mieszkańców parafii Spycimierz, „Twórczość Ludowa” 2018, nr 3-4, s. 27-31.

${ }^{17}$ Zob. film Spycimierskie Boże Ciało, scen. i reż. J. Tatarkiewicz, zdjęcia J. Piwowarski, J. Tatarkiewicz, 2019, na portalu YouTube, online: https://www.youtube.com/watch?v=xkjtijZ_ r7Q [dostęp: 18.03.2020]. 
- kod przedmiotowy, którego przybliżeniu poświęcona jest dalsza część artykułu. Będzie ona próbą odpowiedzi na pytania, jakie przedmioty co znaczą i w jaki sposób stają się znakami w trakcie obrzędowego procesu, jakim jest Boże Ciało w Spycimierzu.

Posłużę się zebranym w Spycimierzu materiałem, na który składają się etnograficzne wywiady terenowe prowadzone przeze mnie oraz innych badaczy (J. Dragan, A.W. Brzezińska, M. Ziółkowska-Kuflińska, K. Dziubata, A. Jełowicki) w latach 2018-2020, wykonane w tym czasie obserwacje uczestniczące ${ }^{18}$, dokumentacja fotograficzna i filmowa. Ważne źródło stanowią materiały archiwalne, fotografie, publikacje albumowe, publicystyczne i naukowe, w większej części dostępne online na stronie Portal Spycimierski ${ }^{19}$.

\section{SPYCIMIERSKI KOD PRZEDMIOTOWY, CZYLI O RZECZACH ZAMIENIANYCH W ZNAKI W CZASIE BOŻEGO CIAŁA ${ }^{20}$}

Z perspektywy semiotycznej w spycimierskim święcie można dostrzec dwa rodzaje przedmiotów: pierwszy to środki, materiały, narzędzia, przedmioty kultu wykorzystywane do wykonania plastycznej oprawy wsi i procesji, zaś druga - wytwory spycimierzan, jak ołtarze, bramy, dywany itd. Mówiąc o pierwszej grupie zauważymy, że w toku przygotowania wsi, obejść czy drogi, jak też w trakcie sprzątania po święcie, wykorzystane zostają przykładowe narzędzia, jak grabeczki (Spycimierz ZG), szczotki (Człopy LŁ) (ryc. 6), zmiotki (Not/AJ), ,miotły, szufle, grabie" (Not/MZK), wiekowy cyrkiel wykonany ze sztachet (Spycimierz ZG), drabina, podnośnik (Zieleń AG), a także środki transportu, jak na przykład motór, wózek (Spycimierz AP), rower, wóz konny, ciagnik, przyczepa (Człopki ES), przyczepka (Spycimierz ZG), traktorek z przyczepką (Not/KD), samochód dostawczy z przyczepą (Not/MZK) itd. Jako zjawiskom znakowym można im przypisać jedynie funkcje rzeczowe w typologii funkcji semiotyków tartusko-moskiewskich $^{21}$, co znaczy, że nie pełnią żadnych poważniejszych funkcji społecznych czy symbolicznych. Aby pokazać, że jednak są ważne i dla społeczności parafian mają

${ }^{18} \mathrm{~W}$ artykule posłużono się transkrypcjami półfonetycznymi wywiadów, cytaty zapisując italiką, podając po nich w nawiasie miejscowość zamieszkania rozmówcy oraz jego inicjały. Rozwiązanie skrótów zamieszczono na końcu tekstu. Notatki terenowe, wykonywane przez badaczy podczas obserwacji uczestniczącej, cytuję prostą czcionką i sygnuję skrótami, również rozwiązanymi pod tekstem.

${ }^{19}$ Portal Spycimierski, online: http://spycimierskiebozecialo.pl/pl/ [dostęp: 15.03.2020].

${ }^{20}$ Ta część stanowi zmienioną wersję jednego z podrozdziałów przygotowanej do druku monografii: K. Smyk, Obrzęd jako tekst kultury. Przykład Bożego Ciała w Spycimierzu, Wyd. Uniwersytetu Marii Curie-Skłodowskiej, Lublin, w druku.

${ }^{21}$ S. Zółkiewski, Teksty kultury. Studia, Warszawa 1988, s. 30-31. 
duże znaczenie, do ich analizy proponuję zastosować teorię K. Pomiana ${ }^{22}$, który ujęcie semiotyczne przeniósł do badań historii, uwzględniające znakowy charakter przedmiotów jako zjawisk posiadających stronę rzeczową i znaczenie. K. Pomian w swojej słynnej i cenionej teorii wyznaczył pięć jednorodnych funkcjonalnie klas przedmiotów, nazwając je CIALAMI, ODPADAMI, RZECZAMI, SEMIOFORAMI oraZ MEDIAMI $^{23}$. RZECZY według niego „są to maszyny, narzędzia, przyrządy, środki transportu, pomieszczenia, ubiory, uzbrojenie, pożywienie, leki" "24, a więc stosowane przez spycimierzan narzędzia i środki transportu mieszczą się w tej kategorii. Jak pisze K. Pomian, pierwotną funkcją RZECZY jest to, że ich „przeznaczeniem jest zmienianie wyglądu lub obserwowalnych właściwości bądź też lokalizacji innych przedmiotów"25. I również stwierdzimy, że grabki, miotły, szczotki będą służyły do zmiany wyglądu i właściwości drogi, poboczy, podwórek spycimierskich, zaś rower, traktorek, ciągnik - do zmiany lokalizacji obiektów i ludzi.

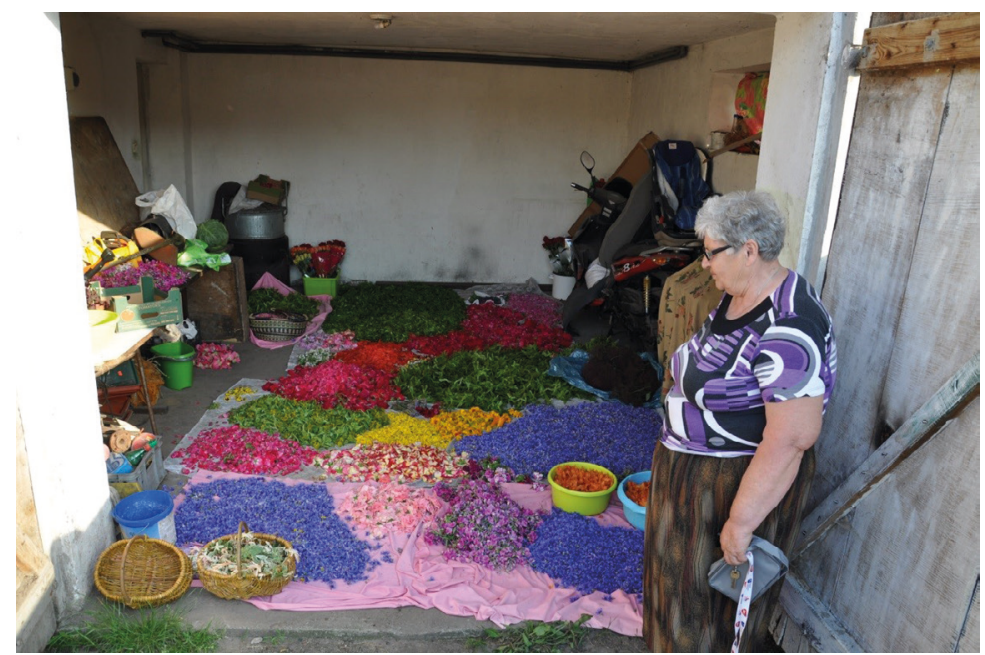

Ryc. 1. Przechowywanie kwiatów zebranych na dywany. Przeddzień Bożego Ciała Źródło: Arkadiusz Jełowicki / Gmina Uniejów, $2019^{26}$

${ }^{22}$ K. Pomian, Historia. Nauka wobec pamięci, przeł. H. Abramowicz, J. Pietrzak-Théblault, Lublin 2006, s. 115-139.

${ }^{23}$ Tamże, s. 120-130.

${ }^{24}$ Tamże, s. 123.

${ }^{25}$ Tamże, 115-139.

${ }^{26}$ Fotografie wykonano w ramach grantu wspófinansowanego przez Ministra Kultury i Dziedzictwa Narodowego z programu „Kultura ludowa i tradycyjna”, noszącego tytuł „Procesja Bożego Ciała z tradycją kwietnych dywanów w Spycimierzu - ochrona i wzmacnianie tradycji" (kierownik - Beata Szymczak, dyrektor Gminnej Biblioteki Publicznej w Uniejowie; koordynator merytoryczny grantu - Katarzyna Smyk; 2019-2020). Ryc. 2 i 3 są publikowane na Portalu Spycimierskim: http://spycimierskiebozecialo.pl/pl/ochrona/ [dostęp: 5.07.2020]. 
Kolejną grupę przedmiotów wykorzystywanych w Spycimierzu do stworzenia świątecznego wystroju również zakwalifikujemy do RzECZY. Będą to przedmioty służące do przechowywania kwiatów: torebki, koszyki, koszyczek (Człopki ES), kartony, skrzynie, tkaniny, doniczki, miski, wazony (Not/MZK); przedmioty wykorzystywane podczas układania wzorów: opryskiwacz do zwilżania podłoża pod dywany (Not/JD), ,nabłyszczacz w spreju [...] do chwilowego zimpregnowania” dywanów, żeby całość „nabrała koloru i lekko się świeciła, jak zwilżona wodą" (Not/KD), wiaderka, konewki, rękawiczki jednorazowe (Not/MZK); przedmioty służące do nanoszenia wzorów na drogę: szablony (Spycimierz KK, MK, $\mathrm{MgK}$ ) z płyty drewnianej, pilśniowej lub folii (Not/MZK, Spycimierz MP) ${ }^{27}$, kreda (Spycimierz KK, MK, Człopy LŁ) (ryc. 1, 2, 3).

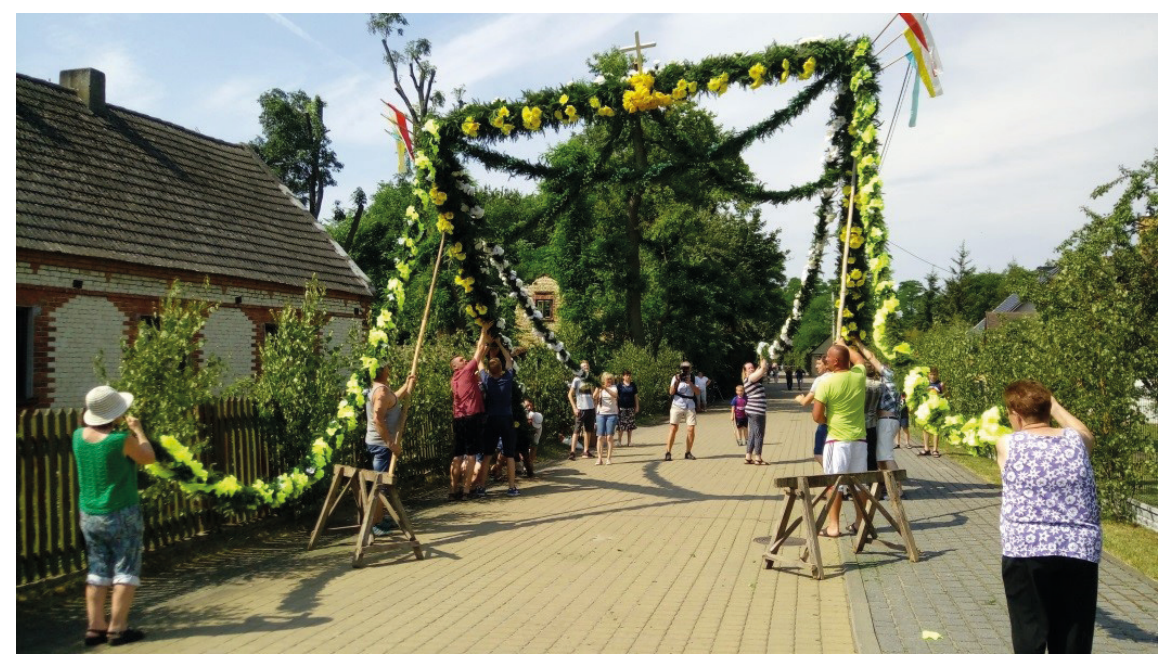

Ryc. 2. Ustawianie bramy przez zespół Marii Pełki. Ranek w Boże Ciało Źródło: Anna Weronika Brzezińska / Gmina Uniejów, 2019

Przyjrzyjmy się następnie materiałom, z których powstaje plastyczna oprawa Bożego Ciała (ryc. 1, 2, 3, 4). Wymienimy tu RzECZY, jak: drut, drągi (Spycimierz MP), wstązki, bibuły, sznurek (Człopy ES), sztuczne kwiaty (Spycimierz AP). Zostają one przechowywane na następny rok, dlatego można je uznać za rodzaj narzędzia, które cyklicznie uczestniczy w przemianie kwiatów, brzózek i innych roślinnych materiałów w ołtarze, szpalery drzewek wzdłuż trasy lub dywany. Kwiaty zaś, inne materiały roślinne, jak kora, trociny (Not/MZK), otręby (Not/ $\mathrm{KD})$, drzewa i części drzewek, patyki (Człopki ES), kamienie (Not/KD), biały piasek, czarniutka ziemia (Spycimierz ZG), woda do zwilżania ziemi (Not/JD/ MZK) (ryc. 3, 6) itp. w klasyfikacji Pomiana nazwiemy CIAŁAMI. Stanowią „od-

${ }^{27}$ Boże Ciało w Spycimierzu. Niematerialne dziedzictwo kulturowe, fotografie i koncepcja albumu J. Tatarkiewicz, [b.m.w.] [2018], s. 5-6. 
rębną klasę funkcjonalną, do której należy wszystko, co ludzie znajdują w swoim otoczeniu" 28 - jak spycimierzanie starają się to, co da im natura, przetworzyć w swoje dzieła. „Surowce, dzikie rośliny i zwierzęta, żywioły, takie jak woda, ziemia, powietrze i ogień $[\ldots]$, nim zostaną przetworzone przez człowieka, nie mają żadnego pierwotnego przeznaczenia"29. Wyliczenie to, po pominięciu zwierząt i ognia, w pełni odpowiada dziełu spycimierskiemu.

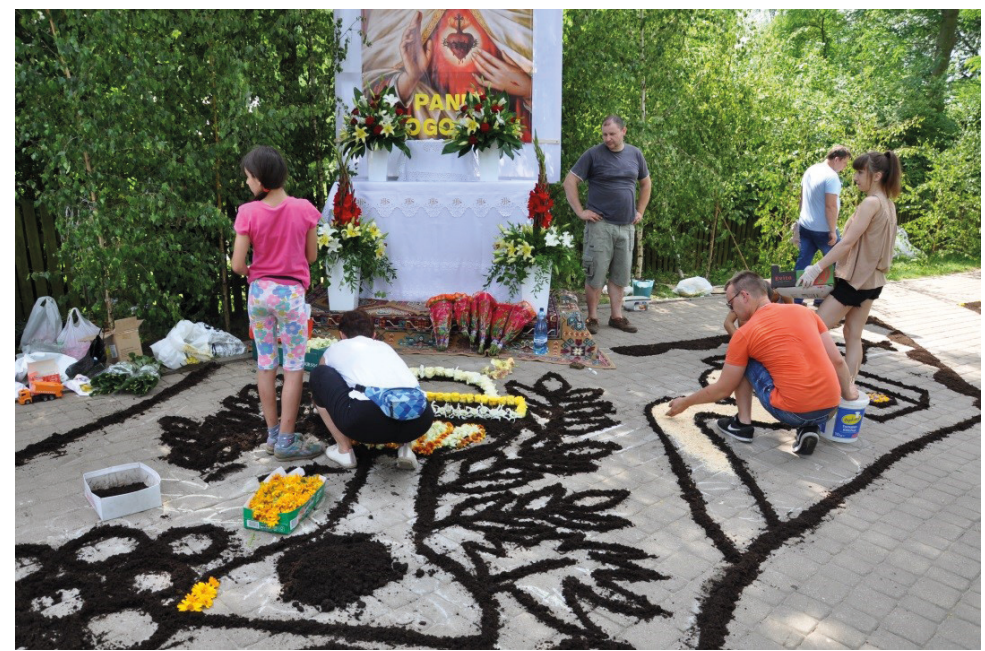

Ryc. 3. Przygotowanie ołtarza i dywanu przez mieszkańców wsi Zieleń. Ranek w Boże Ciało Źródło: A. Jełowicki / Gmina Uniejów, 2019

Dzieło to zaś - efekt procesu kreacji przestrzeni obrzędowej - stanowią bramy, girlandy, ozdobione rzędy brzózek, ołtarze (ryc. 2, 3, 4, 5, 6), włącznie z ołtarzem na placu przykościelnym, i oczywiście kwietne kobierce - atrybut spycimierskiego święta Bożego Ciała (ryc. 4 i 5). Zinterpretujemy je jako SEMIOFORY, czyli przedmioty o wysokiej wartości znakowej, nasycone sensami, najsilniej uznakowione $\mathrm{w}$ procesie semiotyzowania. Proces ten doprowadza do kulminacji ich znaczeń, która przypada na moment rozpoczęcia uroczystej mszy o 17.00, kiedy zdaniem parafian mają doskonałą formę, czyli są skończone, niczego im nie brakuje i są gotowe na przejście procesji eucharystycznej. Możemy więc dostrzec gradacyjny charakter ich uznakowienia, które narasta od chwili planowania wzorów, przez zbieranie kwiatów, ścinanie, zwożenie i wkopywanie brzózek itd., dochodząc do maksimum nasycenia symboliczną treścią $\mathrm{w}$ kulminacji, i następnie - spadają z każdym kwadransem po zakończeniu uroczystości. Pojęcie symbolicznej treści i symbolu, będące ważnymi kategoriami w wielu dziedzinach nauk humanistycz-

${ }^{28}$ K. Pomian, Historia ..., s. 123.
Tamże. 
nych i społecznych ${ }^{30}$, odnosi się do fenomenu o charakterze znakowym. Nie wchodząc w dywagacje, sięgnijmy do definicji autorytetu - M. Lurkera. Pisze on: Symbole $w$ sztuce i religii, $w$ mitach $i$ marzeniach sennych nie sa prostymi odbiciami obiektywnej rzeczywistości, lecz objawiaja sposób bytu wymykajacy się bezpośredniemu doświadczeniu ${ }^{31}$. Dla analizowanego przez nas święta tym objawionym „bytem” jest Chrystus Eucharystyczny, ale też jego relacja do człowieka i wspólnoty istniejąca w historii Kościoła, w danym tu i teraz święcie oraz $\mathrm{w}$ intymnej konfesji każdego spycimierskiego parafianina. Wypunktowane przed chwilą odniesienie do treści symbolicznych zdaje się paralelne do Pomianowskiej funkcji SEMIOFORów, do których należa przedmioty przeznaczone do zastępowania, uzupetniania lub przedtużania wymiany słów badź zachowania jej śladów, czyniąc widzialnym i stabilnym coś, co inaczej pozostałoby ulotne $i$ dostępne tylko dla stuchu. [...] Każdy bowiem odsyła przede wszystkim do czegoś aktualnie niewidzialnego, czego nie można przeto wskazać gestem; można to tylko nazwać lub omówić stowami ${ }^{32}$, które w tradycji spycimierskiej zbiegają się w nazwie święta - Boże Ciało.

SEMIOFORY sa fizycznymi zmianami powierzchni lub bryt, spowodowanymi rozmyślnie w celu zwrócenia uwagi odbiorcy na coś niewidzialnego i zaprogramowania przeto w pożądany sposób jego stanów wewnętrznych i zachowañ ${ }^{33}$. Słowa te opisują sytuację spycimierską, gdzie rzeczywiście zmianie podlega powierzchnia drogi przez ubranie dywanów i w wyniku przejścia po nich procesji. Zmieniają się także kształty ołtarzy przez ich zbudowanie, ozdobienie brzózkami itd. Całość procesu tworzenia wystroju, procesja czy sprzątanie wsi, mają też zwracać uwagę odbiorców - mieszkańców, gości, internautów, telewidzów - i przypominać im o święcie, o wspólnotowości, o wartości pracy poświęconej Bogu. Podziwiają oni na przykład kwietne dywany, oglądając je, jak choćby turyści przybywający thumnie w ostatnich latach do Spycimierza. Pasuje do nich określenie widz, wprowadzone przez K. Pomiana: wszystko to narzuca osobom, które znajduja się w pobliżu, postawę widzów, sktania je do spojrzenia na ten przedmiot i do zatrzymania na nim wzroku. Często przyczynia się do tego cata oprawa [oprawa Bożego Ciała - K.S.], która ma zwrócić nań uwage, pokazać, że obcowanie z nim zmienia tego, kto się weń wpatruje, gdyż wzbogaca go o coś, czego inaczej bytby pozbawiony ${ }^{34}$, choćby zachwytu nad pięknem dywanów i oddaniem spycimierskiej wspólnoty ich tworzeniu.

${ }^{30}$ Na przyklad L. Miodyński, Symbole miejsca w kulturze i literaturze macedońskiej, Katowice 2011, s. 35-53.

${ }^{31}$ M. Lurker, Przestanie symboli $w$ mitach, kulturach i religiach, przeł. R. Wojnakowski, Warszawa 2011, s. 19.

${ }^{32}$ K. Pomian, Historia ..., s. 123-124.

33 Tamże, s. 128.

${ }^{34}$ Tamże, s. 129. 


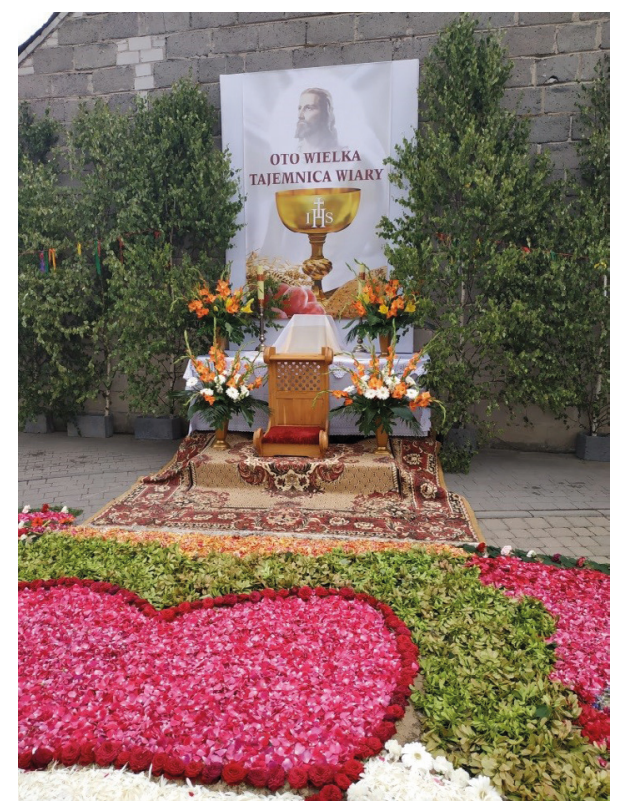

Ryc. 4. Jeden z ołtarzy wraz z dywanem, gotowy na procesję eucharystyczną Źródło: Karolina Dziubata / Gmina Uniejów, 2019

Inne przedmioty, które są istotne w kulminacyjnym czasie święta, to atrybuty procesji: krzyż, feretrony chorągwie, poduszki, baldachim, szarfy (Brdów AK) (ryc. 5), jak też ozdoby domów, gdyż na balkonach, w oknach też powywieszane Matkę Boska, Pana Jezusa (Spycimierz SP). Zaliczą się tu również stroje asysty, jak na przykład haftowane, piękne bluzki ze spódnicami sq we wzorach czerwonych, spódniczki - bialych i zielonych (Brdów AK), kobiecie, męskie, dziecięce i alby, krojone, szyte, haftowane przez parafianki (ryc. 5) bądź - w przypadku elementów wełnianych - zamawiane u krawców z zewnątrz (Spycimierz MP). Te stroje sa w kościele, uszyte specjalnie dla asyst, żeby byto pięknie (Człopy LŁ). Do listy przedmiotów dodać należy stroje komunijne dziewczynek sypiących kwiaty lub odświętne sukienki dziewczynek będących przed Pierwszą Komunią, mundury orkiestry i instrumenty, staranne ubrania parafian i gości itp. Zaliczyć je trzeba do SEMIOFORów, i wraz z analizowanymi wyżej atrybutami święta - do podtypu WYOBRAŻEŃ w typologii K. Pomiana, czyli malowanych, haftowanych, tkanych, wycinanych, rytych, układanych z różnych materiatów, komponowanych z ludzi i przedmiotów, jak w widowiskach [...], komponowanych też z roślin, jak $w$ ogrodach ${ }^{35}$. Użyte przez K. Pomiana słowa haft, układanie z różnych materiatów, kompozycje z roślin zdają się wprost odnosić do strojów asysty i scenografii spycimierskiego święta.

35 Tamże, s. 126. 


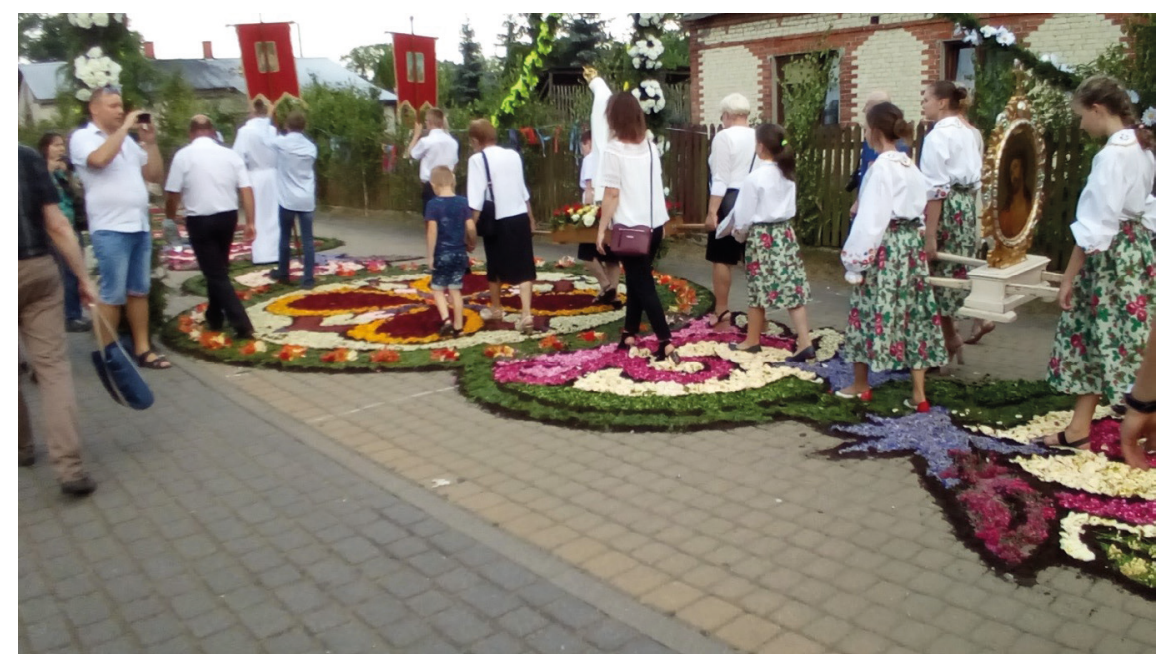

Ryc. 5. Procesja Bożego Ciała idąca po kwietnych dywanach Źródło: A.W. Brzezińska / Gmina Uniejów, 2019

Aparaty fotograficzne, kamery, smartfony wykorzystane do upamiętniania uroczystości (tak powstały choćby zdjęcia ryc. 1-5), jak też sprzęt nagłaśniający wykorzystany podczas mszy oraz autokary i auta, którymi przyjeżdżają turyści, stanowią kolejną grupę elementów z poziomu kodu przedmiotowego, które zaliczyć można do MEDIów. Zgodnie z definicją ${ }^{36}$ ich pierwotną funkcją nie jest współtworzenie spycimierskiego święta, ale dopiero wtórnie służą SEMIOFOROM - a więc znakom ikonicznym i symbolicznym powoływanym do istnienia w Spycimierzu w Boże Ciało, przeksztatcając zazwyczaj obserwowalne tylko zjawiska fizyczne we właściwości postrzegane zmystowo - udostępniają je (auta, sprzęt nagłośnieniowy, kamery) bądź utrwalają (kamery, aparaty) dla zmysłów słuchu i wzroku.

Ostatnia z klas przedmiotów w koncepcji K. Pomiana to ODPADY. Prymarnie skojarzymy je ze zniszczonymi przez procesję dywanami czy brzózkami, które trafiają na kompostowniki, wysypiska, w ogień - w wigilię św. Jana: Bardzo symbolicznie wieś przyjdzie i będa na Jana. [...] Już jest takie ognisko, bo na Jana jest ognisko, noc świętojańska (Spycimierz MgK). Jednakże odPaDY, czyli wszystko, co ludzie porzucaja, usuwaja lub niszczą ${ }^{37}$, towarzyszą na każdym etapie analizowanego procesu obrzędowego. Najpierw przecież dzikie rośliny - chwasty, jak chabry czy maki, więc swego rodzaju ODPADY - zostają zebrane i wykorzystane na dywany; podobnie brzózki czy świerki pochodzą z przecinki w miejscu wskazanym przez leśniczego (Spycimierz SP). OdPaDY są następnie

\footnotetext{
36 Tamże, s. 125.

37 Tamże, s. 123.
} 
produkowane podczas przebierania kwiatów, podczas wycinania szablonów itd. Sprzątanie drogi i podwórek przed świętem oraz po święcie to również pozbywanie się ODPADów. Jednakże można te działania nazwać oddzielaniem ziarna od plew - oddzielaniem RZECZY od ODPADów, by w pierwszej części procesu, doprowadzającego do kulminacji święta, ozdoby wsi składały się z najdoskonalszych przedmiotów, które z pewnością nie mają cech oDPaDów. Druga część obrzędowego procesu to z kolei segregacja przedmiotów: coś staje się ODPADEM, jak rośliny, a jednak coś zostanie przechowane, jak stroje, drut, drągi, stając się RZECZAMI. Na poziomie analizowanego kodu zaznacza się więc swego rodzaju kontinuum: co było RZECZĄ, podczas święta staje się SEMIOFOREM, a po święcie - znów RZECZĄ. Inna klamra: coś, co pochodzi z natury i było ODPADEM w procesie gospodarki (kwiaty, drzewka, piasek), stało się CIALEM w momencie zainteresowania spycimierzan tymi przedmiotami, by zyskać rangę maksymalnie świętego SEMIFORU w trakcie ozdabiania wsi i przejścia procesji, i w końcu - stać się ODPADEM po zakończeniu święta.

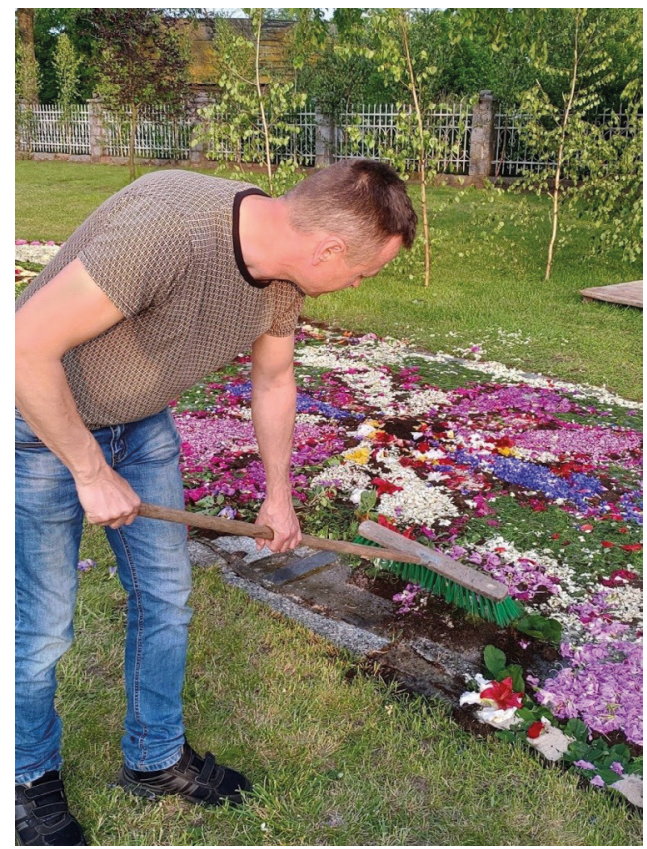

Ryc. 6. Sprzątanie dywanu przez mieszkańców Spycimierza-Kolonii. Boże Ciało po procesji Źródło: Katarzyna Smyk / Gmina Uniejów, 2020 


\section{PODSUMOWANIE, CZYLI SPYCIMIERSKIE KONTINUUM}

Opisane procesy nadawania i utraty znaczeń obrazuje wykres ${ }^{38}$, stanowiący podsumowanie analizy (ryc. 7).

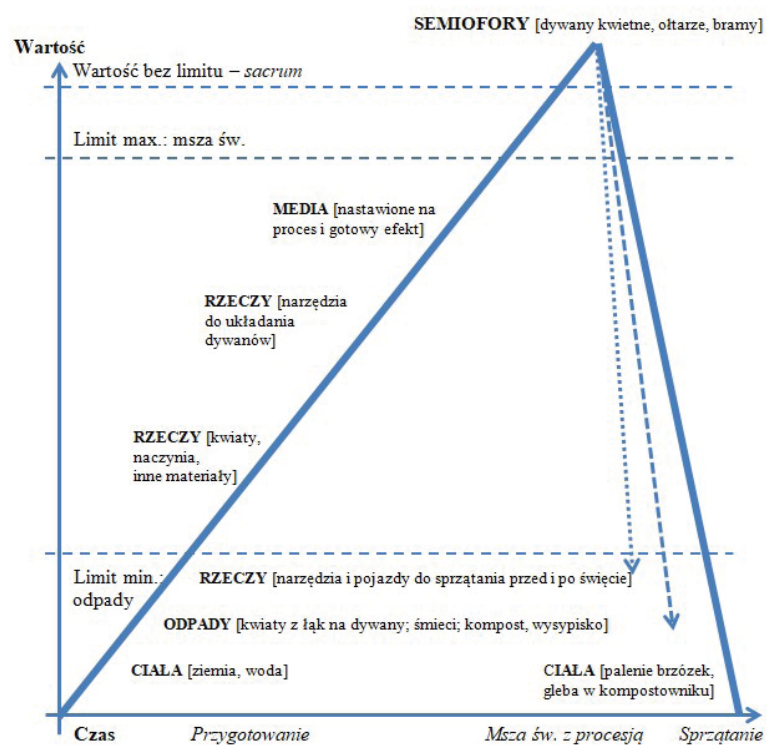

Ryc. 7. Kształtowanie formy i znaczenia semioforów w procesie obrzędowym na przykładzie kwietnych dywanów i ołtarzy na Boże Ciało Źródło: opracowanie własne

Na osi czasu widać długi proces budowania SEMIOFORów - dywanów, bram i ołtarzy, czyli ich fizycznego tworzenia z RZECZY i za pomocą RZECZY - z materiałów z wykorzystaniem narzędzi, przy towarzyszeniu MEDIów - obiektywów aparatów i kamer. Wraz z upływem czasu i w miarę przygotowań, powstające SEMIOFORY zyskują coraz większą wartość i znaczenie - ich maksimum przypada na mszę świętą i procesję, jednakże ta wartość i znaczenie mogą być tak wysokie tylko dzięki temu, że SEMIOFORY w mistyczny sposób „dotykają” sacrum, nabierają znaczenia sacrum i transcendencji, wchodząc w kontakt z Bogiem, a zatem umożliwiając parafianom pożądany kontakt z Chrystusem Eucharystycznym.

${ }^{38}$ Wykres powstał z inspiracji P. Jacksona, posługującego się w swojej teorii ekonomii informacji koncepcją semioforów (wykres Pomian's model of the „semiophore”). P. Jackson, Entropy and Redundancy in Culture, "Method and Theory in the Study of Religion” 2006, t. 18, nr 3, s. 220. Por. K. Smyk, Obrzęd jako tekst kultury..., w druku. 
Po kulminacji następuje proporcjonalnie krótki etap desakralizacji SEMIOFORU i wytracania przez niego symbolicznych funkcji oraz wysokich wartości, aż do przekroczenia limitu ODPADów. Wartość części użytych materiałów (sztuczne kwiaty, drągi bramy, stelaże stoły użyte na ołtarze) obniży się do poziomu RZECZY i zostaną one przechowane do następnego roku, podobnie jak narzędzia, które będą przez ten rok przydatne w gospodarstwie. Część zużytych materiałów zyska czasowo status ODPADów, jak kwiaty wymieszane z ziemią stosowaną do układania dywanów czy więdnące brzózki. I to one zamienią się następnie w CIAŁA - w glebę jak kwiaty i ziemia w kompostowniku, oraz w popiół jak brzózki ogarnięte świętojańskim ogniem - dla zamknięcia kontinuum w wymiarze kodu przedmiotowego. Fizyczne pozbycie się resztek kwiatów z drogi, ziemi i drzewek, które stroiły trasę procesji i ołtarze, można uznać za zamknięcie rocznego cyklu. Otrzymujemy obraz spycimierskiego kontinuum, co wiąże się z obecną w myśleniu tradycyjnym koncepcją czasu cyklicznego, który jest zamkniętym cyklem $z_{m i a n}{ }^{39}$. Kontinuum to można ująć w formułę: co w danym roku było święte, gdyż służyło jako dywan, po którym szedł Jezus Chrystus i błogosławił nasza parafie (Spycimierz MP), przez kolejny rok użyźni glebę, która wyda urodzaj kwiatów. Dzięki nim w następne święta kwietne dywany będą jeszcze piękniejsze i jeszcze bardziej wyrażą cześć parafian spycimierskich dla Boga.

\section{Zastosowane skróty cytowanych materiałów terenowych}

\section{Wywiady terenowe}

Brdów AK - Adriana Kołodziejska, z domu Winnicka, ur. 1978 w Turku, zam. Spycimierz, obecnie, po wyjściu za mąż - w Brdowie (pow. Koło, woj. wielkopolskie, około 50 km od Spycimierza); nagranie 9 listopada 2018, eksplorator, który przeprowadził wywiad i transkrybował J. Dragan.

Człopki ES - Emilia Sobczak, ur. 1929, zam. Człopki od 1950 lub 1951, po zamążpójściu; nagranie 29 czerwca 2018, eksplor. i transkr. K. Smyk.

Człopy LŁ - Lucjan Łukasik, ur. 1958, zam. Człopy, wiceprzewodniczący Rady Miejskiej w Uniejowie; nagr. 10 listopada 2018, eksplor. i transkr. J. Dragan.

Spycimierz AP - Antoni Pietrzak, ur. 1930, zam. Spycimierz od urodzenia, ojciec M. Pełki; nagr. 10 listopada 2018, eksplor. i transkr. J. Dragan.

Spycimierz KK - Kazimiera Karniszewska, ur. 1943, od urodzenia zam. w Spycimierzu; nagr. 10 listopada 2018, eksplor. i transkr. J. Dragan.

Spycimierz MgK - Magdalena Karniszewska, ur. 1974, zam. w Spycimierzu; nagr. 19 czerwca (wigilia Bożego Ciała) i 21 czerwca (dzień po Bożym Ciele) 2019, eksplor. i transkr. K. Dziubata.

Spycimierz MK - Magdalena Koperska, ur. 1976 w Turku, zam. w Spycimierzu; nagr. 10 listopada 2018, eksplor. i transkr. J. Dragan.

Spycimierz MP - Maria Pełka, ur. 1950 w Spycimierzu, zam. w Spycimierzu, prezeska Parafialnego Stowarzyszenia „Spycimierskie Boże Ciało”, liderka lokalna; nagr.: 1 i 29 czerwca 2018, eksplor. i transkr. K. Smyk.

39 J. Szadura, Czas jako kategoria językowo-kulturowa w polszczyźnie, Lublin 2017, s. 72. 
Spycimierz SP - Stanisław Pełka, ur. 1952 w Spycimierzu; mieszka tu od urodzenia; sołtys Spycimierza od wielu kadencji; zakładał 30 lat temu orkiestrę dętą, która m.in. idzie w procesji Bożego Ciała; nagr. 1 czerwca 2018, eksplor. i transkr. K. Smyk; 19 i 21 czerwca 2019, eksplor. i transkr. K. Dziubata.

Spycimierz ZG - Zofia Górka, ur. 1959 w Spycimierzu, wiele lat mieszkała w Łowiczu, siostra Marii Winnickiej; nagr. 29 czerwca 2018, eksplor. i transkr. K. Smyk; 19 i 21 czerwca 2019, eksplor. i transkr. M. Ziółkowska-Kuflińska.

Zieleń AG - Anna Grzelak, ur. 1972, zam. w Zieleniu, sołtyska Zielenia; nagr. 19 i 21 czerwca, eksplor. i transkr. A. Jełowicki.

\section{Notatki z obserwacji uczestniczacej}

Notatki sporządzone w trakcie obserwacji uczestniczącej jawnej w Boże Ciało dnia 20 czerwca 2019, według arkusza obserwacji terenowej pt. „Kwietne dywany na Boże Ciało w Spycimierzu", autorstwa A.W. Brzezińskiej.

Not/AJ - Notatki z obserwacji odcinka dywanu układanego przez mieszkańców wsi Zieleń; obserwował i notatki sporządził A. Jełowicki.

Not/KD - Notatki z obserwacji odcinka dywanu układanego przez rodzinę Stanisława Pełki; obserwowała i notatki sporządziła K. Dziubata.

Not/MZK - Notatki z obserwacji odcinka dywanu układanego przez rodzinę Marii Winnickiej; obserwowała i notatki sporządziła M. Ziółkowska-Kuflińska.

\section{Bibliografia}

Boże Ciało w Spycimierzu. Niematerialne dziedzictwo kulturowe, fotografie i koncepcja albumu J. Tatarkiewicz, [b.m.w.] [2018].

Burke P., Kultura ludowa we wczesnonowożytnej Europie, tłum. R. Pucek, M. Szczubiałka, Warszawa 2009.

Ciesielska-Szynal B., Dekoracje kwiatowe trasy procesji Bożego Ciała w Spicimierzu, „Sieradzki Rocznik Muzealny" 1996, t. 10, s. 31-40.

Douglas M., Symbole naturalne. Rozważania o kosmologii, thum. E. Dżurak, Kraków 2004.

Figlus T., Rozwój układu ruralistycznego Spycimierza na tle dziejów osadnictwa w świetle badań geograficzno-historycznych i archeologicznych, „Biuletyn Uniejowski” 2015, t. 4, s. 73-94.

Hołda R., Boże Ciało. Święto, ceremonia i performans, „Journal of Urban Ethnology” 2013, t. 11, s. 61-74.

Jackson P., Entropy and Redundancy in Culture, „Method and Theory in the Study of Religion” 2006, t. 18, nr 3, s. 219-231.

Kaźmierczak W., Procesja Bożego Ciała z tradycja kwietnych dywanów w Spycimierzu jako krajowe dziedzictwo niematerialne, „Biuletyn Uniejowski” 2018, t. 7, s. 65-75.

Lurker M., Przesłanie symboli w mitach, kulturach i religiach, przeł. R. Wojnakowski, Warszawa 2011.

Łotman J., Uniwersum umystu. Semiotyczna teoria kultury, przekł. i przedmowa B. Żyłko, Gdańsk 2008.

Miodyński L., Symbole miejsca w kulturze i literaturze macedońskiej, Katowice 2011. 
Nowiński J., Ars eucharistica. Idee, miejsca i formy towarzyszace przechowywaniu eucharystii w sztuce wczesnochrześcijańskiej i średniowiecznej, Warszawa 2000.

Ogrodowska B., Zwyczaje, obrzędy i tradycje w Polsce. Mały słownik, Warszawa 2011.

Pomian K., Historia. Nauka wobec pamięci, przeł. H. Abramowicz, J. Pietrzak-Théblault, Lublin 2006.

Pozorski K. SDB, Włoskie pochodzenie tradycji dekoracyjnych uroczystości Corpus Domini, „Biuletyn Uniejowski” 2019, t. 8, s. 67-75.

Rubin M., Corpus Christi. The Eucharist in Late Medieval Culture, Cambridge University Press 1991.

Segalen M., Obrzędy i rytuały współczesne, przekł. J.J. Pawlik, Warszawa 2009.

Smyk K., Kwietne dywany na Boże Ciało w przekazach mieszkańców parafii Spycimierz, „Twórczość Ludowa" 2018, nr 3-4, s. 27-31.

Smyk K., Obrzęd jako tekst kultury. Przykład Bożego Ciała w Spycimierzu, Wyd. Uniwersytetu Marii Curie-Skłodowskiej, Lublin, w druku.

Smyk K., Spycimierskie kwietne dywany na Boże Ciało - typologia i symbolika wzorów, „Biuletyn Uniejowski" 2019, t. 8, s. 35-65.

Szadura J., Czas jako kategoria językowo-kulturowa w polszczyźnie, Lublin 2017.

Tolstoj N.I., Jazyk i narodnaja kul tura. Očerki po slavjanskoj mifologii i etnolingvistike, Moskva 1995.

Tołstoj N.I., Język a kultura (niektóre zagadnienia słowiańskiej etnolingwistyki), przeł. L. Zienkiewicz, J. Bartmiński, „Etnolingwistyka. Problemy Języka i Kultury” 1992, nr 5, s. 15-25.

Zalewski Z., Święto Bożego Ciała w Polsce do wydania Rytuału Piotrkowskiego (1621), „Studia z Dziejów Liturgii w Polsce" 1973, t. 1, s. 95-162.

Zaremska H., Procesje Bożego Ciała w Krakowie w XIV-XVI wieku, [w:] B. Geremek (red.), Kultura elitarna a kultura masowa w Polsce późnego średniowiecza, Wrocław 1978, s. 25-40.

Żółkiewski S., Teksty kultury. Studia, Warszawa 1988.

Żyłko B., Kultura i znaki. Semiotyka stosowana w szkole tartusko-moskiewskiej, Gdańsk 2011.

Żyłko B., Semiotyka kultury. Szkoła tartusko-moskiewska, Gdańsk 2009.

\section{Filmografia}

Spycimierskie Boże Ciało, scen. i reż. J. Tatarkiewicz, zdjęcia J. Piwowarski, J. Tatarkiewicz, 2019, na portalu YouTube, online: https://www.youtube.com/watch?v=xkjtijZ_r7Q [dostęp: 18.03.2020].

\section{Źródla internetowe}

Portal Spycimierski, http://spycimierskiebozecialo.pl/pl/ [dostęp: 15.03.2020]; http://spycimierskiebozecialo.pl/p1/ochrona/ [dostęp: 5.07.2020].

GUS - Bank Danych Lokalnych, https://bdl.stat.gov.pl/BDL/metadane/teryt/miejscowosci/1434\# [dostęp: 15.03.2020]. 


\title{
CHANGING OBJECTS INTO SIGNS. OBJECT-RELATED CODE IN CORPUS CHRISTI TRADITION OF FLOWER CARPETS IN SPYCIMIERZ
}

\begin{abstract}
Summary
The article constitutes a semiotic analysis of items (materials, tools, cult objects) used in Spycimierz (Łódź voievodship, Poddębice county, Uniejów commune) during Corpus Christi celebration. On the national level, the holiday is distinguished by exceedingly rich décor of the village, particularly two-kilometer long flower carpets laid alongside the entire Eucharistic procession route. The author applied the object-related code analysis for the ritual based on the semiophore theory by Krzysztof Pomian. Thus SEMIOPHORES are represented here as flower carpets, gates and altars - elements of the highest sacral value in procession and holy mass. They both emerge from and are created by OBJECTS - materials, tools, assisted by MEDIA - cameras and video cameras. After the procession a SEMIOPHORE desacralisation process occurs, during which they lose symbolic functions and high values they represent. Part of the materials is utilised for further usage next year when they become OBJECTS. The other part, described as WASTE, arrives finally in a composter and transforms into BODIES or soil, out of which flowers will grow the following year. Due to the fact that blossoms will form a flower carpet or decorate an altar, the aforementioned circulation of items can be referred to as "Spycimierz continuum".
\end{abstract}

Keywords: Spycimierz, Corpus Christi feast, flower carpets, semiophores, Krzysztof Pomian, object-related code, intangible cultural heritage

Data nadesłania artykułu: czerwiec 2020

Data akceptacji: lipiec 2020 